\title{
WAS ADHERENCE TO THE GOLD \\ STANDARD A "GOOD HOUSEKEEPING \\ SEAL OF APPROVAL" DURING \\ THE INTERWAR PERIOD?
}

\author{
Michael Bordo \\ Michael Edelstein \\ Hugh Rockoff
}

Working Paper 7186

http://www.nber.org/papers/w7186

\author{
NATIONAL BUREAU OF ECONOMIC RESEARCH \\ 1050 Massachusetts Avenue \\ Cambridge, MA 02138 \\ June 1999
}

This paper was originally prepared for the Symposium in Honor of Lance E. Davis held at Caltech from November 6-8, 1998. For helpful comments we thank Robert Cull, Larry Neal, John Wallis and other participants in the Symposium. We also benefited from the discussion of an earlier draft at the Program meeting of the Development of American Economy group of the NBER, March 6, 1999. For able research assistance we thank Zhu Wang. All opinions expressed are those of the authors and not those of the National Bureau of Economic Research.

(C) 1999 by Michael Bordo, Michael Edelstein, and Hugh Rockoff. All rights reserved. Short sections of text, not to exceed two paragraphs, may be quoted without explicit permission provided that full credit, including $($ notice, is given to the source. 
Was Adherence to the Gold Standard a "Good

Housekeeping Seal of Approval" During the Interwar Period?

Michael Bordo, Michael Edelstein, and Hugh Rockoff

NBER Working Paper No. 7186

June 1999

JEL No. N2

ABSTRACT

World War I dramatically altered the world's financial landscape. Most countries left the gold standard, and New York replaced London as the major lender in world capital markets. This paper discusses how the gold exchange standard was reconstructed in the 1920s. We show that the U.S. capital market viewed returning to the gold standard as a signal of financial rectitude, what we have referred to in other work as a "Good Housekeeping Seal of Approval." When countries returned to gold, especially when they did so at the prewar parity, they were rewarded with the ability to borrow at substantially lower interest rates. Other signals of financial rectitude, such as small fiscal deficits, apparently carried little weight with lenders.

Michael Bordo

Department of Economics

Rutgers University

75 Hamilton Street

New Brunswick, NJ 08901-1248

and NBER

Bordo@economics.rutgers.edu

Hugh Rockoff

Department of Economics

Rutgers University

75 Hamilton Street

New Brunswick, NJ 08901-1248

and NBER

Rockoff@economics.rutgers.edu
Michael Edelstein

Department of Economics

Queens College, CUNY

Flushing NY 11367

mxe\$econ@qc1.qc.edu 


\section{Introduction}

Adherence to fixed parities and convertibility of national currencies into gold served as a signal of financial rectitude or a "good housekeeping seal of approval" during the classical gold standard era from 1870-1914. Peripheral countries that adhered faithfully to the gold standard rule had access at better terms to capital from the core countries of Western Europe than did countries with poor records of adherence (Bordo and Rockoff, 1996) ${ }^{1}$. In this paper we extend the approach developed in that paper to ascertain whether the "good housekeeping seal" was also an important institution under the interwar gold exchange standard, which prevailed only from 1925 to 1931.

In simplest terms, the "good housekeeping seal" hypothesis views the gold standard as a commitment mechanism. Adherence to the fixed parity of gold required that members follow domestic monetary and fiscal policies and have other institutions of financial probity (such as having a monetary authority which holds gold reserves) consistent with long-run maintenance of the peg. It also signaled to potential overseas lenders that the borrowers were "good people". 2

An important part of the hypothesis is that the gold standard should be viewed as a "contingent rule" or a rule with escape clauses. Members were expected to adhere to convertibility except in the event of a well-understood emergency such as a war, a financial crisis, or a shock to the terms of trade. Under these circumstances, temporary departures from the rule would be tolerated on the assumption that once the emergency passed, convertibility at the original parity would resume (Bordo and Kydland, 1995).

\footnotetext{
${ }^{1}$ Also see Flandreau et al (1998).

${ }^{2}$ Our approach is similar to but not the same as the signaling hypothesis first developed by Spence (1974).
} 
An implication of the contingent rule is that the countries which returned to gold parity at a devalued parity after an emergency would be judged as having "weak resolve" and countries which never returned to gold or never adhered would be even worse. In other words, following the gold standard rule served as a signal, other things equal, to lenders that these loans would be safe, both in the sense that they would not be defaulted upon and in the sense that they would not be repaid in a devalued currency. Hence they would charge a lower risk premium to these borrowers than to borrowing countries which were not good gold standard adherents.

In Bordo and Rockoff (1996) we tested this hypothesis for 9 widely different capital importing countries. We found that the risk premium charged on loans in London was lowest for a group of orthodox gold standard countries that never left gold, slightly higher for those countries that temporarily devalued, and still higher for those countries that temporarily left gold and permanently devalued or that never adhered. In this paper we extend this methodology to the interwar gold exchange standard.

The interwar gold exchange standard generally has a bad press. It only lasted six years before collapsing in the debacle of the Great Depression. It is viewed as a flawed attempt to restore the glories of the classical gold standard. Its flaws included the fact that the principle member, the United States, did not deflate sufficiently after the inflation of World War I to restore the real price of gold to its pre-war level, hence imparting a deflationary bias on the system once other countries restored convertibility (Johnson, 1997). It was also flawed because the United Kingdom rejoined gold at an overvalued parity while France did the opposite. Most important however was the fact that the US and France each followed policies of sterilizing gold inflows that exacerbated the underlying disequilibrium. ${ }^{3}$

\footnotetext{
${ }^{3}$ Other flaws stressed in the literature include: the use of multiple reserve countries; an incipient "Triffin dilemma" that the use of foreign exchange as a substitute for increasingly scarce gold would expose the center countries to a
} 
Despite its flaws and bad press, there is compelling evidence that capital markets in the 1920's were as well integrated between the core countries (the US, UK, France and Germany) as they were before the War (Officer 1998, Hallwood and MacDonald, 1998). Also, as we elaborate below, the core counties and most nations attached the highest importance to restoring the gold standard. The gold standard which was restored however was based on somewhat different rules than the pre-war variant. It was a gold exchange standard based on the recommendations of the Genoa Conference of 1922 in which members were encouraged to substitute foreign exchange in dollars or pounds for scarce gold, and the central reserve countries (the US, UK, and later France) were to hold reserves only in the form of gold. Also, gold adherence was explicitly a part of a package of financial orthodoxy encouraged for all members. The packages, first imposed as a part of the League of Nations' stabilization arrangements for the former belligerents, included an independent central bank, a balanced budget and gold convertibility. The package was extended through the efforts of Montagu Norman, Benjamin Strong and Edwin Kemmerer to many peripheral countries.

In sum, one would expect that the "good housekeeping seal" hypothesis should hold in the interwar as it did before World War I. Several important differences between the two regimes however (aside from the flaws of the gold exchange standard) will influence our approach to testing it. The first change is that the mantle of principle lender was passed from the UK to the US, so that most lending to the periphery originated in New York, rather than London. The second difference is that most countries went back to gold at devalued parities. The third is that most countries used foreign exchange as a substitute for gold reserves.

speculative attack as their outstanding liabilities increased relative to their gold reserves; and a lack of credibility compared to the classical gold standard. Because most countries after World War I were concerned with domestic policy goals (the level of real output and employment) their resolve to defend their parities in the face of speculative attack was weakened (Eichengreen, 1992). 
Section 2 of the paper discusses the restoration of the gold standard in the early 1920's, focusing on the diplomatic efforts by the British, and the development of a new order in international finance. Following the Cunliffe Report (1918), the official position was to restore the halcyon days of the pre-war when London was the world's principal capital market. The efforts to return to gold were strongly supported by the US. The process we describe includes concerted policies by the League of Nations and the financial powers to stabilize many countries and private missions to establish central banks. Although the British were the strongest advocates of a return to the "status quo ex ante", they were faced with the growing reality, based on the fact that to finance World War I they had cashed in their overseas assets and borrowed heavily from the US, and after they returned to gold at the original parity in April 1925 that they were under continuous balance of payments pressure, that they did not have the resources to restore the lending network that they had before the war. This was manifested in a series of embargoes on foreign lending in the 1920's. For these reasons, and as an extension of its lending activity to the belligerents that developed during World War I, the US stepped into the breach.

Section 3 describes the evolution of the US role as principal foreign lender. The rise of the US reflected both an extension of wartime lending and its emergence as the strongest economic power. We also consider the indictment that US lending standards were not as strict as those of the British. Although many of the loans issued in the 1920's were defaulted upon in the 1930's, the shock of the Great Depression likely was the main reason for the poor performance.

Section 4 presents our empirical evidence for the "good housekeeping seal" hypothesis. Based on data for 40 countries for 9 years, we estimated a pooled cross-section, time series regression of the interest rates of countries borrowing in the US on several measures of gold standard adherence (whether a country adhered to gold, whether it devalued and whether it was 
on a gold exchange or gold bullion standard) and a set of macroeconomic and other institutional fundamentals. The results strongly confirm those found for the classical gold standard. They show that countries that adhered to gold at whatever parity received better terms than those that did not, and that countries that did not devalue when they returned to gold did better than those that did. Section 5 concludes.

\section{Restoring the Gold Standard}

Economic, Political and Social Conditions as World War I Ended.

At the end of World War I, the United States, Great Britain, France, Germany and many other nations, belligerents or neutral, had swollen money supplies, large debts, large immediate expenditure needs and moderate levels of taxation. All of the belligerents had increased taxes during the war but most of the financing for the war's immense budgets derived from new government debt and money creation. While post-war expenditure needs were lower, even war time levels of taxation were quite inadequate.

Perhaps the most troublesome element affecting economic life was the demand for reparations. The European Allied victors expected post-World War I reparations would cover government budget gaps, especially the severely war damaged countries of Belgium and France. Reparations were also expected to help pay the inter-Allied loans from the United States as the war's net creditor. For Germany the threat and extent of the highly disputed reparations clouded any attempt by its new government to create a stable fiscal and monetary environment for its economy.

An important new element in post-war European politics of finance was that Europe's working classes had become a much more significant force in national politics. All of the 
warring states had made great efforts to gain the support of the working classes and their organizations. Having disproportionately suffered in the war's human toll, some political accommodation to these new voices was certain. Perhaps as important, the 1917 Russian revolution established a communist government which openly encouraged the working classes of Europe to overthrow their capitalist systems.

Finally, all of the warring states and many of the neutrals had been subjected to significant wartime inflation. Except for the United States, the gold standard was suspended by all of the belligerents and many neutrals. From 1914 to 1919 the cost of living multiplied by 1.7 times in the United States, 2.2 in the United Kingdom, 2.7 in France, and 4.0 in Germany. ${ }^{4}$ Through a variety of currency and capital controls Great Britain had uniquely managed to maintain the dollar-pound exchange rate very close to the pre-World War I level throughout the war. However, in March 1919, four months after the war ended Britain was forced to let the pound float.

Considering the Post-War Monetary Standard in 1918-1919

It was thus under these conditions that the question of a post-World War I international monetary system and standard was considered by contemporaries. Although there were a few dissenting voices, the dominant view of governments and central banks in Europe and elsewhere was that a return to the pre-World War I gold standard was highly desirable.

The clear expression of this desire in Great Britain was the Report of the Cunliffe Committee. The committee produced an interim report in August 1918 and a brief final report in December 1918, just after the November Armistice. ${ }^{5}$

4. Mitchell (1975, 743-4). U. S. Department of Commerce (1975, Series E135).

5. First Interim Report of Cunliffe Committee (Cd. 9182). The conclusions of the Interim and Final Reports, as well as the Committee's terms of reference, are reprinted in Sayers (1976, 57-64). 
The August 1918 Interim Report firmly held that Britain should return to the gold standard without delay. The Committee was concerned with the adverse balance of payments, the "undue" growth of credit, and the prospect of a drain leading to a note issue convertibility crisis. Conditions which the Committee thought would be necessary for a return to the gold standard included a cessation of government borrowing, rehabilitation of an effective Bank of England discount rate, and the restoration of the rules governing the currency and note issues and their required reserve backing in the Bank of England's Banking Department.

With regard to gold, the Cunliffe Committee felt that there was no need for an early resumption of internal circulation of gold or bank gold holdings. Gold imports should be free of restriction while permission for gold exports should be obtained from the Bank of England. $£ 150$ million in gold would be a suitable reserve. ${ }^{6}$

In the event, the British balance of payments and fiscal pressures proved too much for the rapid implementation of the Cunliffe recommendations. In late March 1919 official support of the wartime $\$ 4.76$ pound was removed and the next month gold exports were prohibited by law.

Coinciding with the movement to fluctuating exchange rates, the Treasury began to free the capital market from wartime controls. In March 1919 a Treasury notice revised the guidelines for new issues for the still operating wartime Capital Issues Committee. Overseas issues were now permitted, preference being given to those new issues whose proceeds were expended in the United Kingdom, those assisting United Kingdom trade, and Dominion issues. Then, in August and November of 1919 the Defense of the Realm regulations which mandated government regulation of the capital market were repealed.

6. The final report was issued December 3, 1919; it briefly reasserted the conclusions of the Interim Report: Final Report of Cunliffe Com. (Cd. 464). 
Yet, in early 1920 Montagu Norman, Governor of the Bank of England, began to use a policy instrument which heretofore had never been a Bank of England's peacetime policy tool, that is, privately arranged capital embargoes. ${ }^{7}$ Its earliest use seems to have been an embargo on short-term foreign government borrowing, most likely to facilitate the British Treasury's shortterm debt refunding operations. ${ }^{8}$ This first private embargo proved effective; unlike 1919 and 1921 there were no foreign government issues in London in $1920 .^{9}$ Interestingly, some European short-term government borrowers who would have been welcomed in London (or Paris) in the recent past found funding in New York during the embargo year. ${ }^{10}$ This development heralded the shifting of the mantle of the world's center for international finance from London to New York in the following years.

Of the major economies of the world, only the United States was on a fully functioning gold standard, as it had been, with very limited restrictions, throughout the war. ${ }^{11}$ Britain was with the overwhelming majority of nations in the immediate post-war years in carrying on its international transactions with a floating exchange rate. Like Britain these other nations were buffeted by variable exchange rates, inflation and difficult government fiscal problems, and this was a state of financial affairs which did not sit well with their governments or the financial world.

7. Atkin $(1977,28)$ Atkin examines the embargoes throughout the 1920's. See also Moggridge (1971) covering the 1924-1931 years.

8. In May 1920, Norman's diaries note that he had informally arranged with three principal brokers a queue favoring local authority housing and domestic manufacturing firms first, and then, in descending preference, other domestic firms, Dominion and colonial borrowers and, last, foreign borrowers: Sayers $(1976,288)$.

9. Atkin $(1977,155)$.

10. According to Lewis (1938, 640-641), the Belgian and Italian national governments obtained short-term funding from the U. S. in 1920.

11. As of 1919, the United States and Cuba were a gold standard with circulating gold coins while Nicaragua, Panama, and the Philippines were on a gold exchange standard. China was on a silver standard. 
Brussels and Genoa: The International Conferences of 1920 and 1922.

In 1920 at Brussels and 1922 at Genoa, conferences were convened to seek solutions for Europe's evolving post-war financial disorders. At these conferences the first attempts were made to reestablish the international gold standard. Neither of these conferences led the participating nations to move together to implement this goal. Yet, the financial policies concerning national fiscal and currency stabilization which were articulated in the resolutions of these conferences represented a strongly held consensus view on how stabilization might individually proceed, if not in international concert. It is also noteworthy that everyone attending these conferences accepted that fiscal and currency stabilization was a necessary preface for the currency link to gold. Thus, it seems fair to suggest that the Brussels and Genoa conferences articulated a path, a set of fiscal and banking principals and practices which, if implemented, would make the restoration of the gold standard much easier.

Brussels. It was the Council of the League of Nations that called for a Commission on Currency and Exchange to meet in Brussels. Given the reluctance of the U. S. Congress to allow the United States to join the League, American participation consisted of an unofficial observer from the United States Treasury. Even so, as the principal post-war international creditor, American views influenced the proceedings and resolutions, especially Washington's negative view towards the establishment of an international central bank or international credit bank. Until Allied debts to the United States were properly scheduled, private, short-term lending from the United States was the method for dealing with European financial needs approved by Washington. 
The resolutions of the Brussels Commission viewed the growth of inflation as a key cause of disorganization of business, dislocation of exchanges, the increase in the cost of living and labor unrest, and thus a phenomena making it much more difficult to return to pre-war gold parities. $^{12}$ Inflation could be stopped by abstaining from increasing the currency. The chief cause of excessive currency expansion was excessive government expenditure. Governments had to limit their current expenditures to their current revenues and avoid all "superfluous" expenditures. Banks, especially Banks of Issue, "should be freed of political pressure and should be conducted solely on lines of prudent finance." ${ }^{13}$ Additional credit creation and new floating government debt should cease; repayment or funding should begin.

With regard to an international monetary standard, Brussels' Resolution VIII stated that a return to the gold standard was highly desirable, but it was impossible to forecast when the older countries would be able to return "to their former measure of effective gold standard or how long it would take the newly formed countries to establish such a standard". ${ }^{14}$ "Deflation, if and when undertaken, had to be carried out gradually and with great caution." 15

A notable resolution of the Brussels Conference was a call for the creation of central banks in countries where none were currently in place and " .. if the assistance of foreign capital were required for the promotion of such a Bank some form of international control might be required." ${ }^{16}$ This latter phrase was all that remained of the hotly debated ideas for an

12. Sayers $(1976,69-73)$. Many of the key international and British monetary documents of the interwar decades are republished in this source, the third volume of Sayer's (1986 [1976]) excellent history of the Bank of England from 1891 to 1944.

13. Sayers $(1976,70)$

14. Sayers (1976, 70).

15. Sayers (1976, 72).

16. Sayers (1976, 73). 
international bank of issue and an international credit bank, opposed by the United States'

unofficial delegate, among others. But, it does adumbrate the idea, if not the specifics, of the

League's later financial missions which were to begin in 1922.

Genoa. The Genoa Conference of April-May 1922 was the second international

conference called by the Council of Allies to address the continued national and international

financial instability. Called with the support of Great Britain, France, Belgium, Italy and Japan, it was hoped, again unrequited, that the Americans would send official representation. Perhaps the most active planning for the Genoa Conference was undertaken by the Bank of England and the U. K. Treasury, with a fairly heavy input from Montagu Norman, the Bank's Governor. ${ }^{17}$ Draft proposals brought to Genoa by the British delegation were among those accepted by the conference's Financial Commission.

A set of widely agreed upon economic and political conditions for national fiscal and currency stabilization, quite similar to the Brussels' list, formed an important part of the final conference resolutions. The most controversial Genoa proposals were three important resolutions concerning international monetary arrangements, quickly named the gold exchange standard. These were: (1) central banks should conduct their credit policy so as to avoid undue fluctuations in the purchasing power of gold; (2) central banks were to cooperate continuously

17. A draft of proposed resolutions was circulated and shared with, among others, Benjamin Strong, the Governor of Federal Reserve Bank of New York, 1914-1928. Strong was Norman's closest American contact with the Federal Reserve System and New York's financial markets. Strong's links to the Bank of England stemmed from the Federal Reserve Bank of New York's role as the U.S. Government's official agent for international transactions from 1916 onward. Norman, in turn, was one of the most knowledgeable Britons in high office on U. S. monetary and business affairs. Before Norman joined the Bank of England first as Deputy Governor, 1918-1920, and then Governor, 19201944, he had been an associate and then partner of Brown-Shipley, an American mercantile/private banking firm with British partners. His rise through the ranks of Brown-Shipley involved several extended stays in the U. S. Norman's American background and contacts must have impressed the Directors of the Bank when he was offered the Deputy Governorship in 1918, a background which could only help in dealing with Britain's principal wartime creditor and the world's largest industrial power. From the beginning of Norman's Bank career, Strong and Norman carried on a frequent and extremely frank correspondence. Indeed, Norman had visited the United States in September 1921 to improve the Bank of England's relations with the Federal Reserve System, both beginning and ending his stay with Strong in New York: Clay (1957); Chandler (1958); Sayers (1986 [1976], ). 
with each other; and (3) central banks were divided into two groupings - (a) the central countries which were to hold their international reserves entirely in gold and (b) the other nations (unnamed) which were to hold their international reserves partly in gold and partly in foreign exchange, that is, short-term credits on the center countries. International reserves, in other words, could be highly liquid credits placed in the center countries.

In formulating these proposals Norman and the Bank of England saw the world's supply of gold as limited. Britain herself had taken gold coin out of circulation to conserve Britain's holdings. However, it was also the case that these gold exchange standard proposals served national British interests, as was recognized by the U. S. and France, the other "central" economies.

The British could expect to have a very large share of these short-term credits deposited in London by the world's lesser central banks. Regardless of any temporary embargo on longterm foreign borrowers, Britain remained the dominant market for short-term credit funding of world trade in the early 1920s. Furthermore, these London sterling deposits of foreign banks could be a very accessible source of temporary reserves for the Bank of England when, as happened in the years 1906-1910, the Bank was subject to pressures from Britain's balance of payments. ${ }^{18}$

The Return of Gold, 1922-1931.

In 1919, there were five nations in the world on the gold standard, the United States, Cuba, Nicaragua, Panama and the Philippines. Notably, the latter four were closely linked to the

18. For example, the Bank of Japan's London reserves were regularly borrowed by the Bank of England at least from 1905 onward: Sayers (1986 [1976], 40-41); Suzuki (1994, 167-170). During these same years, the Bank of Japan kept foreign currency reserves in New York, Berlin, and Paris. 
U. S. By end of 1922 Costa Rica, Salvador and Lithuania had restored their link to the standard. Of these seven, Cuba and the United States were on a gold coin standard, the rest were on a gold exchange standard. At the peak of the interwar gold standard in 1929, forty-six nations were part of the gold standard system. China remained on the silver standard while Russia, Turkey, Portugal and Spain continued to maintain fluctuating exchange rates. Thus, in a much shorter space of time than characterized the spread of the gold standard in the 19th century, most of the world's nation states and their empires had rejoined the gold standard.

Obviously, there were economic incentives for such return. Restoring the gold standard meant the direct and indirect costs of exchange rate fluctuation were sharply minimized which, in turn, could have important effects on the costs of short- and long-term finance and the volume of trade. Moreover, a nation on the gold standard was a nation which was likely to keep its government expenditures in line with its tax revenues and thus not meet any large portion of its expenditures with paper money creation. Furthermore, a gold standard government was likely to think that international commerce and finance was a valuable aspect of national economic and social progress. Finally, a gold standard country was not likely to single out foreign businesses for differential treatment in taxation or in courts of contract law.

Even with these advantages for a nation state the immediate economic costs of restoring the gold standard might be quite high, often involving ending an inflationary fiscal policy with significant output and employment effects. It was also politically difficult, particularly in nations where the working classes were finding their voice on matters of taxation and government expenditure and the wealthy classes were unwilling to accept an altered burden. As Eichengreen (1992) makes abundantly clear, new taxes and new expenditures supported by newly widened voting franchises and stronger working class parties were a significant and widespread stumbling 
block in attempts to restore the gold standard during the 1920s. Indeed these factors as well as the extent to which the price level had to decline, determined whether countries would return to gold at the prewar parity or at devalued rates.

When the gold standard was restored in the 1920s it usually involved several stages, with national fiscal and currency stabilization coming first, often accompanied by the creation or reform of the central bank. Then, the nation might move to de facto exchange rate stabilization in terms of gold, with de jure exchange rate stabilization somewhat later.

\section{International Financial Missionaries}

In the early stages of national fiscal and currency stabilization and sometimes in the later process of gold standard restoration, the speed and character of the process was frequently and importantly affected by foreign missions. The 1920s must be the most intense decade of financial missionary activity the world had ever seen. The League of Nations sent financial missions to advise Central and Eastern Europe. British, American, and French central bankers officially and unofficially offered advice and financial help. The American economist Kemmerer and other private financial experts were widely used in Latin America and elsewhere.

The common ideology of these missions was forged in the Brussels and Genoa meetings and defined more sharply through each mission's experience. Brown later summarized these ideas, calling them a program of cooperation: "to balance national budgets and stop inflation; to direct the flow of long term capital to countries financially and economically disorganized by the war and to safeguard that capital; to generalize and develop the institution of central banking and safeguard the independence of central banks; to adopt measures of gold economy; to reach a settlement of past debts". ${ }^{19}$

19. Brown $(1940,346)$. The ideas can be repeatedly found in League of Nation reports and annuals. What is equally important is their frequent mention in the correspondence of Norman and Strong in the 1920s. Perhaps the most famous 
The League of Nations Missions. In August of 1922 Austria asked the Allied Powers for financial help and was referred to the Council of the League of Nations. A mission was set up to investigate Austria's financial problems and make recommendations. Norman was deeply involved from the start, having a hand in the appointment of several members of the Austrian mission. In March 1923 new statutes for an Austrian central bank emerged and the Bank of England issued a 12-month loan (March 1923). Three months later in June, a long-term, Leaguebacked loan was floated in London, New York, Paris and elsewhere and the Austrian currency was formally linked to gold. Norman saw the Austrian mission as a demonstration of the kind of cooperative international financial help which could work and be replicated elsewhere. ${ }^{20}$

Hungary came to London seeking similar help in March 1923 and was referred to the League. With a settlement of a reparation issue arranged in March 1924, two months later a bridging short-term loan was taken by the Bank of England, a large long-term, League-backed loan was placed internationally, and a fixed link to gold emerged. ${ }^{21}$ League long-term loans were also the outcome of stabilization missions to Greece $(1924,1928)$, Danzig $(1925,1927)$, Bulgaria $(1926,1928)$ and Estonia (1927). In total $£ 81.2$ million in long term, League of Nation backed, loans were placed. Britain absorbed $49.1 \%$ and the U. S. 19.1\%. Austria, Belgium, Czechoslovakia, France, Greece, Holland, Hungary, Italy, Spain, Sweden and Switzerland absorbed shares of 1-6\%. ${ }^{22}$ Norman and Strong's support of this type of international cooperation was clearly evident.

example is Norman's memorandum listing the general principals of central banking, drafted by Norman sometime in 1921, reviewed and amended by Strong: Sayers (1976, 74-5).

20. Sayers $(1976,168-171)$

21. Sayers (1976, 172-173).

22. Eichengreen (1989a, 119). 
Key Country Support for Key Country Restorations. The return of the gold standard in the financially troubled principal European economies in the 1920s was also generally supported by international advice and cooperation. However, in these important cases the international aspects of their return were directly in the hands of the principal financial powers. Such was the circumstance for Germany (1924) and Britain (1925). Two financial powers of the second rank, Belgium (1925) and Italy (1927), were also helped by the principal financial powers. The principal exception to cooperation among the key monetary powers concerns the French run up to de facto restoration in December 1926 and its de jure restoration in June 1927. As Eichengreen has recently suggested, the particularly acute fiscal and currency crisis in France created a very strong attachment to a purely gold reserve which conditioned their de facto return to gold in December 1926 and de jure return in June 1927 and their attempt to pursue this created riffs with the British and others. ${ }^{23}$

As early as 1919, Strong suggested to Norman that if the principal financial powers first cooperated to stabilize their own government finances and restore the gold standard amongst themselves, it would then be far easier for the other nations to find guidance and resources to stabilize and restore the gold standard following the principal financial powers. ${ }^{24}$

Indeed, American involvement was crucial in the 1923 international commission to help Germany deal with her reparations obligations and get beyond the national and international log jams that produced its devastating post-war hyperinflation. Its outcome, the Dawes Plan, depended critically on official U. S. support and private U. S. participation in the Dawes Loan of 800 million gold marks of foreign currency. Negotiated over the summer of 1924, it was issued

23. Eichengreen (1992, 172-183, 196-7). See also Clarke (1967, 112-140).

24. John H. Williams, the Harvard economist who is given credit for originating the key currency idea, was an advisor to Strong: Clarke (1967, 40-41). 
in New York, London, Paris and other European capital markets in October. The United States absorbed half of the loan (\$110 million) and the United Kingdom took a quarter; France, Belgium, the Netherlands, Italy, Sweden and Switzerland took the rest. In the same month, the new gold mark was repegged to gold.

Britain's own return to gold in April 1925 was strongly supported by Strong and the New York capital market. A fundamental condition for such a return was a deflation of British prices relative to the United States, which proved elusive despite secularly high unemployment rates, the Bank of England's vigilant positioning of its discount rate and occasional foreign loan embargoes. However, the longer Britain waited the more likely it was that the foreign exchange reserves of newly stabilized currencies would be deposited in New York, not London. Indeed, in the winter of 1924-1925 first Australia and South Africa and then Switzerland and the Netherlands put Britain on notice that they wished to complete their post-war financial stabilization by restoring the gold standard. ${ }^{25}$

On April 28, 1925, Churchill announced that Britain was back on the gold standard at $\$ 4.86$ to the pound. The Bank of England had $£ 153$ millions in gold reserves, virtually the amount recommended by the Cunliffe Committee. Significantly, credits of $\$ 300$ millions had been arranged, if needed, consisting of a $\$ 100$ million credit from J. P. Morgan and other American banking houses and a $\$ 200$ million repo line of gold from a number of Federal Reserve Banks for two years.

As things evolved, the American credits were not used but Norman did find it necessary to arrange a private embargo on foreign loans from November 1924 to facilitate the expected return and an embargo on colonial loans was added two months after the April 1925 restoration.

25. Pressnell (1978), Tsokhas (1994), Eichengreen (1992, 190-191). Sweden, Germany, and Hungary had stabilized their currencies in 1924, Sweden and Germany establishing a de jure link to gold. 
Only in November 1925 was the situation thought sufficiently stable to lift the embargoes. ${ }^{26}$ These embargoes most likely hastened the decline of the London international capital markets and the shift to the unfettered environment of New York.

The Money Doctors. The third international force for monetary stabilization was the missions of Princeton economist Kemmerer and other private consultants. Since Kemmerer regularly corresponded and met with Strong of the New York Federal Reserve Bank and the State Department concerning his missions, it would appear that he was comfortable operating within the parameters of American monetary and diplomatic policy. Yet, the governments hiring Kemmerer clearly wanted an independent U. S. consultant, not a seconded official of the U. S. central bank or its diplomatic corps. That these governments wanted a foreigner suggests that they were trying to avoid petty political attacks directed at native experts; that they wanted a U. S. consultant suggests they wanted access to American financial markets. Kemmerer, it was well known, had excellent contacts with Dillon, Reed. In the 1920s, Kemmerer headed or jointly chaired missions to Peru (1922), Colombia (1923), Guatemala (1924), South Africa (1924-1925), Chile (1925), Poland (1926), and Bolivia (1927), as well as serving on the Dawes Commission to Germany in 1925.

Kemmerer's agenda was virtually the same as the missions of the League of Nations: fiscal stabilization, creating an independent central bank, and stabilizing the currency in terms of gold, de facto and de jure. ${ }^{27}$ Measured by whether Kemmerer's missions resulted in the restoration or establishment of a gold standard, the evidence suggests that it was usually the case

\footnotetext{
26. From June to November 1925 only one Empire loan was issued in London and not one foreign government loan was issued during the whole of 1925: Atkin $(1977,51)$.

27. Eichengreen (1989b, 60-64).
} 
that within a year of a Kemmerer mission, the local currency was stabilized in terms of gold. ${ }^{28}$ With regard to the effects the Kemmerer missions had on enhanced foreign dollar loans, Eichengreen found a significant effect on national government loans within three years of a Kemmerer mission. $^{29}$

Kemmerer's efforts may have indirectly had a significant effect on the return to gold of a key economy. The advice of the Vissering-Kemmerer commission formed an important basis for the South African government's decision to inform Great Britain that South Africa wanted to return to gold as soon as possible. As was noted earlier, the privately expressed desire of South Africa, Australia, Switzerland and the Netherlands to return to gold in late 1924 and early 1925 put substantial pressure on Great Britain to speed its own return in April 1926.

Thus with the efforts of the great powers, especially the United Kingdom and the United States, the League of Nations, and private missions, the gold standard was restored as a gold exchange standard. Many countries accompanied their return to convertibility with deliberate actions to attain fiscal probity including establishing a central bank and a balanced budget. Also because of the severity of the wartime inflation and dislocations and the rising power of labor, many countries returned to gold at devalued parities. The United Kingdom was a principal advocate and architect of the restoration of the gold standard, presumably to restore its position as the world's premier capital market. Yet as events unfolded, she was denied this role and the mantle shifted to New York. This transformation reflected the United Kingdom's weakened financial status after the war manifested in embargoes on international lending and the decision to return to gold at the original parity which overvalued sterling.

28. See Eichengreen (1989b) for a list of Kemmerer missions and Eichengreen (1992, 188-190) for Kemmerer's exhaustive list of nations on the gold standard, 1919-1937. 


\section{The Mantle Shifts}

Prior to World War I the United States was a debtor nation, similar to Canada, Australia, and other developing countries that were absorbing European capital and exploiting their natural resources. There was, however, considerable U.S. foreign investment, especially towards the end of the nineteenth century. Most, was direct investment by American corporations that were expanding their operations abroad. There was also some foreign portfolio investment. ${ }^{30}$ The $^{2}$ rapid growth in both direct investments and foreign security holdings in the period 1900 to 1914 , moreover, suggests that the United States would have become a major foreign investor, and would have changed from debtor to creditor, even in the absence of World War I. ${ }^{31}$

World War I, however, accelerated this transition. The outbreak of the war in Europe brought foreign governments into the American market seeking loans. During the period of U.S. neutrality these loans were generally short term. Indeed, the volume of short-term lending grew so rapidly that in January 1917 the Federal Reserve felt compelled to warn the banks against acquiring too many foreign short-term loans.

American entry into the war led to massive foreign loans by the US government. The mechanism was simple. The Treasury itself became the purchaser of long-term bonds issued by the Allies. During the war the Capital Issues Committee controlled sales of foreign securities on private markets.

29. The missions seem to have had little or no effect on short term or non-government foreign dollar loans: Eichengreen (1989b, 66-67).

${ }^{30}$ Direct Investment rose from 635 million to 2652 million between 1897 and 1914; secruity holdings rose from 50 million to 862 million. (Lewis 1938, 445).

${ }^{31}$ The surge in U.S. foreign investment and its political ramifications are discussed in (Davis and Cull, 1994, 92107). 
After the war, U.S. foreign investment boomed. Europe had been devastated by the war and needed capital to restore plant and equipment. Europe also needed capital to reconstruct financial relationships; going on the gold standard meant holding gold or foreign exchange convertible into gold. Britain, although a victor, and possessing lending institutions built up over centuries, was drained by the war. America was ready to replace Britain as the center of lending for developing countries.

Table 1 shows the basic dimensions of U.S. foreign lending during the twenties. Over the years 1919 to 1932 some $\$ 5.2$ billion (at face value) in national and provincial government securities, our focus in this paper, were floated in the American market. At market prices the figure would be closer to $\$ 5$ billion. The total, which includes corporate and municipal securities as well as nationals and provincials, was about $\$ 9$ billion at face value. Most of these were longterm (more than five years) bonds. These were dollar bonds, so that exchange risk was being assumed, at least from a legal point of view, by the borrower.

Issues were substantial even in 1919. National and Provincial issues peaked in 1924, while total issues, driven by corporates, peaked in 1927. National and Provincial flotations declined sharply in 1929 as investors focused on the soaring returns in the stock market, revived in 1930, and then collapsed as the Great Depression took hold. The purpose of the loans changed over the twenties. The earliest loans were refunding loans needed to finance short-term obligations incurred during the war, and reconstruction loans needed to finance rebuilding of capital damaged in the war, especially railways. Later came stabilization loans, including the Dawes plan loans to Germany which helped establish the post-hyperinflation German currency. And last came what might be called development loans, directed at a wide range of countries, with the purpose of providing social overhead capital. 
The list of countries that sought and obtained dollar loans in the American market in the twenties is a long one. It included major European powers such as France and Germany, smaller European countries such as Bulgaria and Lithuania, South American countries such as Argentina, Brazil, and Chile, and many others. These bonds were distributed by a small number of investment banking houses. J.P. Morgan \& Co. was the most important, serving as the lead firm on perhaps half the issues. The others important players were Kuhn, Loeb; Dillon, Read; National City Company; and J.W. Seligman.

The central factor behind the growth of the market was simply that there was good business to be done. Foreigners wanted to borrow; Americans (and few others) had capital to lend. Behind the scenes the U.S. government offered encouragement. Foreign lending was seen as a way of promoting a stable political equilibrium in Europe, and of extending American influence in other regions. Beginning in 1921, the State Department reviewed proposed flotations. ${ }^{32}$ Generally, the Department offered no objection to a proposed loan, but there were a few exceptions based on political considerations. The Department for example, did not object to Japanese loans if the money was to be used in Japan, but it did object if the money would be used in Manchuria.

During the Great Depression many of the foreign governments that the United States had lent to in the twenties defaulted, including Germany, Bulgaria, Brazil, Cuba, and China. Many municipal and corporate borrowers, of course, defaulted as well. Inevitably, it was argued that lending standards had been lax in the twenties, that they had fallen even further as the lending "mania" progressed, and that the resulting defaults had contributed to the severity of the Depression. On the surface it seemed that although the United States had taken over the role of

\footnotetext{
${ }^{32}$ Cleveland and Huertas, $(1985,147)$.
} 
principal overseas lender from the British, they had not acquired the expertise that the British had accumulated over a century of practice. It also suggests that US lenders may not have followed the same criteria to evaluate foreign loans as the British.

A number of pieces of evidence were adduced to show that standards had been lax. First there was the quantitative evidence. By the end of the 1930s billions of dollars worth of bonds were in default, and the majority were issues made later in the twenties rather than earlier. There was also an abundance of qualitative evidence. One oft-repeated story concerns the son of the President of Peru who was later convicted of "illegal enrichment" in connection with a Peruvian issue. Another frequently repeated story concerns Cuba. Initially it's foreign borrowing was intended to complete a road running from one end of Cuba to the other, a badly managed project perhaps, but one that could be justified as a productivity increasing investment in social overhead capital. Later, as the willingness of Americans to lend became evident, the Cubans borrowed for less justifiable purposes - a new Capitol with a gilt dome. ${ }^{33}$ And, as with the stock market, one could cite many warnings by wise men that speculation was running wild in the foreign bond market, and that a day of reckoning was at hand.

The problem with this evidence, of course, is that it is hard to know what would have happened in the absence of the Great Depression. Although some borrowers would have defaulted, the number defaulting would have been far smaller, fewer scandals would have been detected, and the warnings of the Casandras would have been forgotten. Foreign loans in the twenties did contain substantial risk premiums. To say whether those premiums were "reasonable" would mean knowing a reasonable estimate of the probability of an extremely unlikely event: a collapse of the American financial system in which the Federal Reserve failed to act as lender of last resort followed by a prolonged world-wide depression. 
Some attempts have been made to address the standards issue. Friedman and Schwartz (1963, 245-8) provide a perceptive analysis of the standards debate, and of the studies, such as Mintz (1951), available at the time. ${ }^{34}$ Friedman and Schwartz argue that the real problem might not have been excessively low credit standards in the 1920s, but rather excessively high standards in the early 1930s, especially at the Federal Reserve.

The critics of U.S. foreign lending in the 1920s, both at the time and since, seem to have assumed that it should have been relatively straightforward for lenders to assess the quality of a foreign issue, a matter mostly of judging the particular project that was to make use of the borrowed capital, combined, perhaps, with some judgment about the weight of the borrowers' total debt burden. Judging the soundness of the issue of a sovereign borrower, however, involves a difficult problem of asymmetric information. The real question is how much a particular country will be willing to suffer in hard times to repay obligations contracted in good times, a piece of information that is hard for lenders to know, whether the borrower is a local businessman or a sovereign nation.

Our research explores how the US capital markets in the 1920s attempted to solve the asymmetric information problem. Our hypothesis is that the US lenders looked at whether a country had made the effort to go on the gold standard, as was the case when Great Britain was the principal lender, and if possible to do so at the prewar price of gold.

\footnotetext{
${ }^{33}$ Lewis, 1938, pp. 383-87.

${ }^{34}$ Mintz computed an annual default index based on the ultimate status of a borrower, rather than of a particular loan, thus adjusting for loans that were not defaulted because they had been substantially repaid before the depression, and concluded that standards had fallen in the late 1920s.
} 


\section{Methodology, Data, Econometric Evidence}

In this section we present evidence for the "good housekeeping seal of approval" hypothesis for the interwar period. Our approach is to estimate a very simple pooled crosssection time series regression for 40 countries and seven years of data. ${ }^{35}$ The regression tests to see if adherence to the gold standard affected the interest rate that was charged on dollar denominated loans to sovereign borrowers in the U.S. capital market, holding constant other fundamentals. We also ascertain whether in addition to adhering to gold convertibility it mattered whether a country had devalued its currency before restoring the gold standard.

This methodology is somewhat different from that followed in Bordo and Rockoff (1996). In that study which covered the classical gold standard period 1870 to 1914 we had a 40 year sample of data for only 9 countries. In that study most of the variation came from the time dimension in contrast to this study which relies mainly on the cross-section variation. ${ }^{36}$

The interest rates which we use come from a study by Cleona Lewis (1938). ${ }^{37}$ She presented a comprehensive tabulation of new issues in the U.S. markets and the rates charged for approximately 40 countries. ${ }^{38}$ Its likely that these were not the only countries that were borrowing in international markets. But this was, as discussed in section 3, the most important bond market in the interwar period. The data is organized so that we only use observations for years in which the countries actually borrowed. We do not know why they did or did not borrow. A decision not to borrow might reflect bad credit, and an inability to borrow at low rates, or

\footnotetext{
${ }^{35}$ For the data sources and definitions used see the Data Appendix.

${ }^{36}$ In that study we estimated the Betas from a CAPM regression as well as the simpler regressions reported here.

${ }^{37}$ We thank Barry Eighengreen for drawing our attention to this source.

${ }^{38}$ The countries in our sample are (in Europe) Austria, Belgium, Bulgaria, Czechoslovakia, Danzig, Denmark, Estonia, Finland, France, Germany, Great Britain, Greece, Hungary, Ireland, Italy, Lithuania, Netherlands, Norway, Poland, Rumania, Sweden, Switzerland, Yugoslavia; (in the New World) Canada and Newfoundland, Argentina, Bolivia, Brazil, Chile, Colombia, Peru, Uruguay, Costa Rica, Cuba, the Dominican Republic, Guatemala, Haiti, Panama, El Salvador; and (in the rest of the world), Australia, China, the Dutch East Indies, Japan, Liberia, and the Phillipine Islands.
} 
simply an abundance of domestic savings. During this period there were also a number of important stabilization loans offered under the auspices of the League of Nations as mentioned in section 3 above. In the empirical work described below we omit these loans because they do not fit exactly into the framework of our hypothesis - they were made by private lenders but were officially backed on political grounds to help countries stabilize their inflation rates and return to gold. We also did our calculations including these loans in the sample and the results were quite similar.

We used a number of institutional variables to isolate various dimensions of the "good housekeeping seal" hypothesis. These include dummy variables to ascertain whether it mattered whether a country was on or off gold, whether it had devalued, whether it followed a gold exchange standard or a pure gold standard, whether a gold coin or gold bullion standard.

The third set of variables is a set of macroeconomic fundamentals that one might think would be important in judging a country's ability to service its debts. These variables include a measure of monetary policy (the rate of growth of the stock of money less the rate of growth of real output), the inflation rate, a measure of fiscal policy (the ratio of government expenditures less receipts relative to GNP), the ratio of the current account deficit relative to GDP, the rate of change of the exchange rate, the central bank discount rate, the ratio of gold reserves to total reserves, and the ratio of total reserves to imports. The definitions are shown in Table 2 .

Before we examine the regressions it is useful to look at the interest rates for our sample of countries dividing the sample into the countries that were on gold and off gold in the years 1920-1929. ${ }^{39}$ As can clearly be seen from figure 1 the interest rate for gold standard adherents was less than for non-adherents. Before 1925 the difference is about 100 basis points and

\footnotetext{
${ }^{39}$ The sample presented in these figures excludes stabilization loans.
} 
afterwards closer to 200. A further demarcation, as shown in figure 2, divided the sample into 3 groups: off gold, on gold and devalued, and on gold and not devalued. From figure 2 it can clearly be seen that interest rates for the last group are considerably lower than for the other groups. ${ }^{40}$ Furthermore, after 1925 the interest rates for the on gold and devalued group is about 100 basis points below the off-gold group. These results suggest that good gold standard orthodoxy commanded a very high premium. But even attempting to go back to gold at a devalued parity was better than not doing so.

The advantage to a country of returning to gold can be seen in many individual cases. Thus for example Canada paid 5.53 percent when off gold and 4.65 percent when on gold; Australia paid 6.9 and 5.17; Chile 8.05 and 6.75; Denmark 6.93 and 4.8, and Italy 7.8 and 6.25. Indeed figure 3 shows for the whole sample, the interest rates paid in the two years before going back onto gold and the rates paid in the three years after. As is clearly evident there is a dramatic decline.

We turn now to the regression results. In Table 3 we regress the interest rates on the onoff gold dummy, the dollar amount of the issue scaled by GDP, and a number of macroeconomic variables. All the regressions also include year dummies which to save on space are not presented. The first equation is the simple benchmark equation which includes only the gold adherence dummy. As can be seen, this variable is significant and has the predicted negative sign. Equation 2 adds in the size of the issue and the following fundamentals: inflation, fiscal policy, foreign trade, and the exchange rate. As in equation (1) the gold adherence dummy is significant, indeed it is more significant and negative, and two of the other variables are significant, inflation and the exchange rate. We have also included the White $t$ statistics which adjust for possible heterocedasticity. These results are similar, although the significance of the

\footnotetext{
${ }^{40}$ Some new countries did not have a prewar parity to go back to. They are omitted from the sample at this point.
} 
on-off dummy is higher and the exchange rate is now significant at the 5 percent level, but with a perverse sign. Equation (3) substitutes our measure of monetary policy for the inflation rate. As in the previous regression this variable is significant.

In Table 4 for the gold standard adherence dummy we substitute two dummies: countries that were on gold that did not devalue, and countries that were on gold and did devalue. The ongold not devalued dummy is significant at the 1 percent level and is considerably stronger than the on-gold dummy in Table 3. Also as in the previous table the inflation variable is strongly significant. The only other variable that is significant is the exchange rate in equation (3).

Finally, Table 5 repeats the equations from the previous two tables, except that we add in two additional fundamental variables: the ratio of gold reserves to total reserves and the ratio of total reserves to imports. The key finding in this table, as in table 4, is that the on-gold-notdevalued dummy comes in with the right sign, is strongly significant, and large in magnitude (over 200 basis points). ${ }^{41}$

As a test of the robustness of our results we ran a similar set of regressions (but do not present the results here) on a different set of interest rates. These are long term bond yields for ten countries used in Bordo and Schwartz (1996). Our results were quite similar to those in Table 3, but somewhat weaker.

In sum, the results for our measures of gold adherence, especially orthodox gold adherence-- that is returning to the prewar parity-- we believe provides strong support for the "good housekeeping seal" hypothesis. As in our earlier study the variables that one might at first

\footnotetext{
${ }^{41}$ We ran regressions similar to those in Tables 4 and 5 including dummy variables to ascertain whether it mattered if a country was on a gold exchange or pure gold standard and whether it was on a gold coin or gold bullion standard. It did not appear, however, that these further distinctions had a significant impact. Finally we ran the regressions using one year lags on the fundamental variables. The results were similar.
} 
think should serve as fundamentals, with the principal exceptions of inflation and monetary policy, did not turn out to be that strong.

\section{Conclusion}

Although this paper tests the "good housekeeping seal of approval hypothesis" that two of us worked on previously, we were all somewhat skeptical that it would apply to the 1920's. The interwar monetary system has generally received a bad press. It got off to a bad start, as many countries delayed in returning to gold, and many returned at devalued parities. It lasted for only a brief period before ending in the disaster of the Great Depression. Moreover, it was not a true gold standard, but rather a gold exchange standard which by definition made it more fragile. It has been characterized as having major fundamental flaws which led to a deflationary bias, and most importantly it has been indicted because members had less of a credible attachment to gold orthodoxy. Yet there is significant recent evidence which suggests that when the gold standard functioned, arbitrage in the short-term capital markets was as efficient as it had been before 1914 , and there were substantial long-term capital flows in the 1920's.

Yet despite these reservations, the regression results we report in section 4 were very encouraging for our hypothesis. The on-gold-off-gold dummy was as significant as what we found for the pre-1914 period, and the fact that the coefficient on the on-gold-never-devalued dummy was even stronger suggests that adherence to gold standard orthodoxy was highly prized by US lenders. However, the fact that adhering to gold even at a devalued parity was valued suggests that the markets attached importance to being part of the fixed exchange rate system independent of following gold standard orthodoxy. 
The general insignificance of the other fundamentals, with the principal exceptions of inflation and monetary policy, echoed what we found in our earlier study. We do not have a ready explanation, but it is possible that the markets preferred the gold standard seal over data that had only recently become available, and that they could not easily evaluate.

While we believe these results to be compelling, a number of reservations are in order. These include the fact that we could have tested for the influence of other fundamentals such as the political variables considered by Eichengreen (1992) and Simmons (1994): left wing versus right wing governments, longevity of the government, and so on. Or other variables such as prior commercial linkages between the lenders and the borrowers, geography, and a common language, and culture.

While our results show that countries would have received a large gain by going back to gold at the prewar parity it is understandable why they chose not to do so. In most cases returning to the prewar parity would have required substantial deflation and likely declining real activity. In the face of a dramatically changed political economy with the rise of the left and the power of organized labor, the costs of pursuing such a strategy likely outweighed the benefits that we have identified in terms of the spread between the coefficient on the on-off-gold dummy and the on-gold-never-devalued dummy. A case in point is France which even at the lowest point of postwar inflation in 1919 would have had to deflate by a multiple of the amount that the British and Americans deflated. 


\section{Bibliography}

Atkin, John Michael. 1977. British Overseas Investment. 1918-1931. New York NY: Arno Press. [Ph. D., University of London, 1968].

Board of Governors of the Federal Reserve System. 1944. Banking and Monetary Statistics. Washington, DC.

Bordo, Michael D. 1993. "The Bretton Woods International Monetary System: An Historical Overview," In Michael D. Bordo and Barry Eichengreen (eds.) A Retrospective on the Bretton Woods System: Lessons for International Monetary Reform. Chicago: University of Chicago Press.

Bordo, Michael D. and Anna J. Schwartz. 1996. "The Operation of the Specie Standard: Evidence for Core and Peripheral Countries, 1880-1990" in Historical Perspectives on the Gold Standard: Portugal and the World. edited by Barry Eichengreen and Jorge Braga de Macedo. London: Routledge.

Bordo, Michael D. and Barry Eichengreen. 1998. "The Rise and Fall of a Barbarous Relic: The Role of Gold in the International Monetary System.” NBER Working Paper 6436. March.

Bordo, Michael D. and Finn E. Kydland. 1995. "The Gold Standard as a Rule: An Essay in Exploration" Explorations in Economic History. Vol. 32. No.2. October. pp. 423-464.

Bordo, Michael D. and Hugh Rockoff. 1996. "The Gold Standard as a 'Good Housekeeping Seal of Approval” Journal of Economic History. Vol. 56. No.2. June. pp. 389-428.

Brown Jr., William Adams. 1940. The International Gold Standard Reinterpreted. 1914-1934. New York NY: NBER. [Reprinted, New York NY: Arno Press, 1970].

Cavallo, Domingo and Yair Mundlak. 1985. Estadísticas de la evolución económica de Argentina, 1913-1984. Buenos Aires.

Chandler, Lester V. 1958. Benjamin Strong, Central Banker. Washington: Brookings.

Clarke, Stephen V. O. 1967. Central Bank Cooperation: 1924-1931. New York NY: Federal Reserve Bank of New York.

Clay, Henry. 1957. Lord Norman. London: Macmillan; New York: St. Martin's Press.

Cleveland, Harold van B. and Thomas F. Huertas. 1985. Citibank 1812-1970. Cambridge: Harvard University Press.

Davis, Lance E., and Robert J. Cull. 1994. International Capital Markets and American Economic Growth, 1820-1914. Cambridge: Cambridge University Press. 
Eichengreen, Barry. 1989a. The U. S. capital market and foreign lending, 1920-1955. Ch. 3 in Sachs, Jeffrey (ed.). Developing Country Debt and Economic Performance. Vol. 1. The International Financial System. Chicago IL: NBER/University of Chicago. Pp. 107-155.

Eichengreen, Barry. 1989b. House calls of the money doctor: the Kemmerer missions in Latin America, 1917-1931. In Calvo, Guillermo (ed.). Debt, Stabilization and Development: Essays in Memory of Carlos Diaz Alejandro. Oxford: Basil Blackwood.

Eichengreen, Barry. 1992. Golden Fetters. The Gold Standard and the Great Depression. 19191939. New York NY: Oxford University Press.

Flandreau, Mark, Jacques Le Cacheux and Fredric Zumer. 1998. "Stability Without a Pact? Lessons from the European Gold Standard, 1880-1914" Economic Policy. April. pp.117162.

Friedman, Milton and Anna J. Schwartz. 1963. A Monetary History of the United States 18671960. Princeton: Princeton University Press.

Hallwood, Paul, Ronald MacDonald, and Ian Marsh. 1996. "Credibility and Fundamentals: Were the Classical and Interwar Gold Standards Well Behaved Target Zones?" in Tamin Bayoumi, Barry Eichengreen and Mark Taylor (eds). Economic Perspectives on the Classical Gold Standard. Cambridge: Cambridge University Press.

IBGE. 1990. Estatisticas Historicas do Brasil: Series Economicas, Demograficas e Socias de 1550 a 1988. Rio de Janeiro.

International Monetary Fund. (various years). Annual International Financial Statistics. Washington, DC.

Johnson, H. Clark. 1997. Gold, France and the Great Depression 1919-1932. New Haven: Yale University Press.

Lewis, Cleona. 1938. America's Stake in International Investments. Washington DC: The Brookings Institute.

Mintz, Ilse. 1951. Deterioration in the Quality of Foreign Bonds Issued in the United States, 1920-1930. New York: NBER.

Mitchell, B. R. 1975. European Historical Statistics 1750-1970. New York NY: Columbia University Press.

Mitchell, B.R. 1992. International Historical Statistics: Europe. New York: Stockton Press.

Mitchell, B.R. 1993. International Historical Statistics: the Americas. New York: Stockton Press. 
Mitchell, B.R. 1995. International Historical Statistics: Africa, Asia and Oceania. New York: Stockton Press.

Moggridge, D.E. 1971. British controls on long term capital movements, 1924-1931. Ch. 4 in McCloskey, D.N. (ed). Essays on A Mature Economy: Britain After 1840. London: Methuen.

Officer, Lawrence. 1996. Between the Dollar-Sterling Gold Points: Exchange Rates, Parity and Market Behavior. Cambridge: Cambridge University Press.

Pressnell, L.S. 1978. "1925: the Burden of Sterling." Economic History Review, Vol. 31, No. 1, February, pp. 67-88.

Sayers, R. S. 1976. The Bank of England. 1891-1944. Appendixes. Cambridge: Cambridge U. Press.

Sayers, R. S. 1986 [1976]. The Bank of England. 1891-1944. Vol. 1 \& 2 Cambridge: Cambridge University Press. [First hardback edition, 1976; first paperback edition, 1986, reprinted with corrections].

Simmons, Beth. 1994. Who Adjusts? Princeton: Princeton University Press.

Spence, A. Michael. 1974. Market Signalling: Information Transfer in Hiring and Related Processes. Cambridge, MA: Harvard University Press.

Suzuki, Toshio. 1994. Japanese Government Loan Issues on the London Capital Market 18701913. London UK: Athlone.

Tsokhas, Kosmos. 1994. "The Australian Role in Britain's Return to the Gold Standard." Economic History Review, Vol. 47, No. 1, February, pp. 129-146.

U. S. Department of Commerce. 1975. Historical Statistics of the United States, Colonial Times to 1970, Bicentennial Edition. 2 vols. Bureau of the Census. Washington DC: GPO. 


\section{Appendix: Data Sources}

In this study we use 1920-1929 annual data for the following 40 countries:

Argentina, Australia, Austria, Belgium, Bolivia, Brazil, Bulgaria, Canada, Chile, China, Colombia, Costa Rica, Cuba, Czechoslovakia, Denmark, Egypt, Ecuador, Estonia, Finland, France, Germany, Greece, Hungary, Italy, Ireland, Japan, Mexico, the Netherlands, Norway, Panama, Peru, Poland, Portugal, Romania, Spain, Sweden, Switzerland, the United Kingdom, the United States and Yugoslavia.

Bond Issues (The value of the issues in million of U.S. dollars): Lewis, (1938), pp. 632-636.

CPI (Consumer Price Index): Mitchell, (1993), pp. 696-699, 700-702; Mitchell (1992), pp. 848849; Mitchell, (1995), pp. 930, 935, 939. (For Mexico and Yugoslavia, we use WPI (Wholesale Price Index), Mitchell, (1993), pp. 691; Mitchell, (1992), pp. 842.

Devalued or Not (An institutional dummy variable indicating whether or not a country has devalued after returning to the gold standard): Bordo and Schwartz, (1996), pp. 20-22.

Exchange Rates (Cents per unit of domestic currency): Board of Governors of the Federal Reserve System, (1944), pp. 662-682.

Exports (In domestic currency in millions): Mitchell, (1993), pp. 420-431, 435-438; Mitchell (1992), pp. 558-562; Mitchell (1995), pp. 507, 524, 525, 537.

Foreign Exchange Reserves (In millions of U.S. dollars): Bordo and Eichengreen, (1998), pp. 74-75.

Gold Reserves (In millions of U.S. dollars): Bordo and Eichengreen, (1998), pp. 74-75.

Gold Type (An institutional dummy variable indicating types of the gold standard-gold bullion, gold coin, gold exchange and etc.): Eichengreen, (1992), pp. 188-190.

Government Expenditure (In domestic currency in millions): Mitchell, (1993), pp. 653-664, 659-662; Mitchell, (1992), pp. 799-801; Mitchell, (1995), pp. 872, 882, 887.

Government Revenue (In domestic currency in millions): Mitchell, (1993), pp. 668-677, 680682; Mitchell, (1992), pp. 816-825; Mitchell, (1995), pp. 894, 906, 914.

Imports (In domestic currency in millions): Mitchell, (1993), pp. 420-431, 435-438; Mitchell, (1992), pp. 558-562; Mitchell, (1995), pp. 507, 524, 525, 537.

Interest Rates (The rates of interest in percent on new issues of dollar denominated bonds): Lewis, (1938), pp. 632-636. 
Money Supply (Depending on the availability of data, we use M1 or M2): Mitchell, (1992) (1993) (1995), Bordo, (1993), Cavallo and Mundlak, (1993), International Financial Statistics Yearbooks, Various Years; IBGE (1990).

Nominal GDP (In domestic currency in millions): Mitchell, (1993), pp. 748-775; Mitchell, (1992), pp. 889-912; Mitchell, (1995), pp. 987-1022.

On Gold or Not (An institutional dummy variable indicating whether or not a country has returned to the Gold Standard): Eichengreen (1992), pp. 188-190.

Real GDP (In domestic currency in millions): Mitchell, (1992), pp. 748-775; Mitchell, (1992), pp. 889-912; Mitchell, (1995), pp. 987-1022. 
</ref_section> 


\begin{tabular}{|c|c|c|c|c|c|c|}
\hline & Long 7 & $\begin{array}{l}\text { Term Foreign D } \\
\text { (Millio }\end{array}$ & $\begin{array}{l}\text { Table 1 } \\
\text { ar Loans N } \\
\text { f Dollars, }\end{array}$ & $\begin{array}{l}\text { ade by Th } \\
919-1932\end{array}$ & United States & \\
\hline & National ar & ad Provincial G & rnments & & All Borrowe & \\
\hline Year & $\begin{array}{l}\text { New } \\
\text { Issues }\end{array}$ & Retirements & Net & $\begin{array}{l}\text { New } \\
\text { Issues }\end{array}$ & Retirements & Net \\
\hline 1919 & 534.4 & 17 & 517.4 & 639.1 & 25.4 & 613.7 \\
\hline 1920 & 290.1 & 3.6 & 286.5 & 421.9 & 20.2 & 401.7 \\
\hline 1921 & 365.2 & 44 & 321.2 & 526.3 & 57.1 & 469.2 \\
\hline 1922 & 509.9 & 139 & 370.9 & 716.1 & 173.6 & 542.5 \\
\hline 1923 & 231.9 & 54 & 177.9 & 329.5 & 72.8 & 256.7 \\
\hline 1924 & 676.9 & 57.7 & 619.2 & 908.6 & 103.6 & 805 \\
\hline 1925 & 551.6 & 114.2 & 437.4 & 918.4 & 139 & 779.4 \\
\hline 1926 & 436.7 & 105.5 & 331.2 & 884.1 & 160.3 & 723.8 \\
\hline 1927 & 584.8 & 63.5 & 521.3 & 1238.9 & 157.8 & 1081.1 \\
\hline 1928 & 486.3 & 256.1 & 230.2 & 1165.1 & 404.5 & 760.6 \\
\hline 1929 & 97.4 & 380.6 & -283.2 & 372.8 & 440.1 & -67.3 \\
\hline 1930 & 432.7 & 120.1 & 312.6 & 757.2 & 285.8 & 471.4 \\
\hline 1931 & 75.1 & 217.9 & -142.8 & 198.8 & 345.3 & -146.5 \\
\hline 1932 & 0 & 151 & -151 & 0.7 & 333.6 & -332.9 \\
\hline TOTAL & 5273 & 1724.2 & 3548.8 & 9077.5 & 2719.1 & 6358.4 \\
\hline tes: & e at & arue. & & & & \\
\hline
\end{tabular}


Table 2

Definitions of The Variables

\begin{tabular}{|c|l|l|}
\hline & On Gold & A Dummy Variable, 1 if a country fits the criterion \\
\hline & On Gold and Devalued & A Dummy Variable, 1 if a country fits the criterion \\
\hline & On Gold not Devalued & A Dummy Variable, 1 if a country fits the criterion \\
\hline & Gold Coin and Bullion & A Dummy Variable, 1 if a country fits the criterion \\
\hline Institutional Variables & Gold Exchange & A Dummy Variable, 1 if a country fits the criterion \\
\hline & Gold Coin and Bullion not Devalued & A Dummy Variable, 1 if a country fits the criterion \\
\hline & Gold Coin and Bullion and Devalued & A Dummy Variable, 1 if a country fits the criterion \\
\hline & Gold Exchange not Devalued & A Dummy Variable, 1 if a country fits the criterion \\
\hline & Gold Exchange and Devalued & A Dummy Variable, 1 if a country fits the criterion \\
\hline & & \\
\hline & Monetary Policy & Money supply growth rate less real GDP growth rate \\
\hline & Inflation & Rate of change of the CPI \\
\hline & Fiscal Policy & The change in government debt divided by nominal GDP \\
\hline Macroeconomic Variables & Foreign Trade & The trade balance divided by nominal GDP \\
\hline & Exchange Rate & The exchange rate \\
\hline & Gold Reserves/Total Reserves & Gold reserves divided by total reserves \\
\hline & Total Reserves/ Imports & Total reserves divided by Imports \\
\hline & & Growth rates are calculated using log differences. \\
\hline & & \\
\hline Scale Variable & Issues/GDP & Bond issues in dollars divided by nominal GDP \\
\hline
\end{tabular}


Table 3

POOLED REGRESSIONS

DEPENDENT VARIABLES:INTEREST RATES (1920--1929)

\begin{tabular}{|c|c|c|c|c|c|c|c|c|c|c|}
\hline Regressions & Intercept & on Gold & Issue/GDP & Monetary Policy & Inflation & Fiscal Policy & Foreign Trade & Exchange Rate & Adjusted $\mathrm{R}^{2}$ & $\mathrm{~N}$ \\
\hline (1) & $\begin{array}{l}7.85^{* *} \\
(9.74)\end{array}$ & $\begin{array}{l}-1.25^{*} \\
(2.57)\end{array}$ & & & & & & & 0.23 & 53 \\
\hline (2) & $\begin{array}{l}7.87 \\
(10.65)^{* *} \\
{[9.03]^{* *}}\end{array}$ & $\begin{array}{l}-1.28 \\
(2.72)^{* *} \\
{[3.73]^{* *}}\end{array}$ & $\begin{array}{l}-18.74 \\
(1.37) \\
{[1.35]}\end{array}$ & & $\begin{array}{l}6.11 \\
(2.33)^{*} \\
{[2.80]^{* *}}\end{array}$ & $\begin{array}{c}7.91 \\
(1.62) \\
{[1.51]}\end{array}$ & $\begin{array}{l}1.25 \\
(0.34) \\
{[0.35]}\end{array}$ & $\begin{array}{l}0.14 \\
(1.03) \\
{[2.29]^{*}}\end{array}$ & 0.42 & 53 \\
\hline (3) & $\begin{array}{l}8.05 \\
(10.63)^{* *} \\
{[10.01]^{* *}}\end{array}$ & $\begin{array}{l}-1.44 \\
(2.85)^{* *} \\
{[4.26]^{* *}}\end{array}$ & $\begin{array}{r}-20.41 \\
(1.33) \\
{[1.62]}\end{array}$ & $\begin{array}{l}4.33 \\
(2.26)^{*} \\
{[3.00]^{* *}}\end{array}$ & & $\begin{array}{c}8.37 \\
(1.47) \\
{[1.21]}\end{array}$ & $\begin{array}{l}2.15 \\
(0.56) \\
{[0.62]}\end{array}$ & $\begin{array}{l}0.17 \\
(1.36) \\
{[2.96]^{* *}}\end{array}$ & 0.39 & 49 \\
\hline
\end{tabular}

* significant at 5 percent level.

** significant at 1 percent level

Note: Absolute values of t-statistics are in parentheses. Absolute values of White t-statistics are in brackets.

Estimation results of year dummies are omitted in the table. 
Table 4

POOLED REGRESSIONS

DEPENDENT VARIABLES:INTEREST RATES (1920--1929)

\begin{tabular}{|c|c|c|c|c|c|c|c|c|c|c|c|}
\hline Regressions & Intercept & $\begin{array}{l}\text { on Gold } \\
\text { not Dev. }\end{array}$ & $\begin{array}{l}\text { on Gold } \\
\text { and Dev. }\end{array}$ & Issue/GDP & Monetary Policy & Inflation & Fiscal Policy & Foreign Trade & Exchange Rate & $\operatorname{AdjR}^{2}$ & $\mathrm{~N}$ \\
\hline (1) & $\begin{array}{c}7.56^{* *} \\
(12.14)\end{array}$ & $\begin{array}{l}-2.24 * * \\
(5.41)\end{array}$ & $\begin{array}{l}-0.32 \\
(0.79)\end{array}$ & & & & & & & 0.54 & 53 \\
\hline (2) & $\begin{array}{c}7.46 \\
(12.83)^{* *} \\
{[15.03]^{* *}}\end{array}$ & $\begin{array}{l}-2.03 \\
(5.15)^{* *} \\
{[4.87]^{* *}}\end{array}$ & $\begin{array}{l}-0.35 \\
(0.86) \\
{[0.98]}\end{array}$ & $\begin{array}{l}-3.32 \\
(0.30) \\
{[0.29]}\end{array}$ & & $\begin{array}{l}5.74 \\
(2.81)^{* *} \\
{[2.98]^{* *}}\end{array}$ & $\begin{array}{c}6.18 \\
(1.61) \\
{[1.24]}\end{array}$ & $\begin{array}{c}2.45 \\
(0.84) \\
{[0.86]}\end{array}$ & $\begin{array}{c}0.07 \\
(0.66) \\
{[1.28]}\end{array}$ & 0.65 & 53 \\
\hline (3) & $\begin{array}{c}7.43 \\
(11.34)^{* *} \\
{[15.75]^{* *}}\end{array}$ & $\begin{array}{l}-1.95 \\
(4.40)^{* *} \\
{[5.30]^{* *}}\end{array}$ & $\begin{array}{l}-0.33 \\
(0.64) \\
{[0.85]}\end{array}$ & $\begin{array}{c}2.50 \\
(0.18) \\
{[0.19]}\end{array}$ & $\begin{array}{l}1.82 \\
(1.05] \\
{[1.13]}\end{array}$ & & $\begin{array}{c}4.57 \\
(0.93) \\
{[0.76]}\end{array}$ & $\begin{array}{c}4.58 \\
(1.40) \\
{[1.35]}\end{array}$ & $\begin{array}{l}0.13 \\
(0.11) \\
{[2.13]^{*}}\end{array}$ & 0.57 & 49 \\
\hline
\end{tabular}

* significant at 5 percent level.

** significant at 1 percent level.

Note: Absolute values of t-statistics are in parentheses. Absolute values of White t-statistics are in brackets.

Estimation results of year dummies are omitted in the table. 
Table 5

POOLED REGRESSIONS

DEPENDENT VARIABLES:INTEREST RATES (1920--1929)

\begin{tabular}{|c|c|c|c|c|c|c|c|c|c|c|c|c|c|}
\hline Regressions & Intercept & on Gold & $\begin{array}{l}\text { on Gold } \\
\text { not Dev. }\end{array}$ & $\begin{array}{l}\text { on Gold } \\
\text { and Dev. }\end{array}$ & Issue/GDP & $\begin{array}{l}\text { Inflation/ } \\
\text { M Policy }\end{array}$ & $\begin{array}{l}\text { Fiscal } \\
\text { Policy }\end{array}$ & $\begin{array}{l}\text { Foreign } \\
\text { Trade } \\
\end{array}$ & $\begin{array}{l}\text { Exchange. } \\
\text { Rate }\end{array}$ & $\begin{array}{l}\text { Gold Reserve } \\
\text { Total Reserve. }\end{array}$ & $\begin{array}{l}\text { Total Res } \\
\text { Import }\end{array}$ & $\operatorname{Adj}^{2}$ & $\mathrm{~N}$ \\
\hline (1) & $\begin{array}{l}7.17 \\
(4.58)^{* * *} \\
{[5.01]^{* * *}}\end{array}$ & $\begin{array}{l}-1.16 \\
(1.27) \\
{[1.97]^{*}}\end{array}$ & & & $\begin{array}{l}-38.38 \\
(1.73)^{*} \\
{[1.97]^{*}}\end{array}$ & $\begin{array}{c}6.66 \\
(1.06) \\
{[1.36]}\end{array}$ & $\begin{array}{l}4.82 \\
(0.64) \\
{[0.71]}\end{array}$ & $\begin{array}{l}-0.15 \\
(0.02) \\
{[0.02]}\end{array}$ & $\begin{array}{l}-0.09 \\
(0.04) \\
{[0.04]}\end{array}$ & $\begin{array}{c}0.95 \\
(0.69) \\
{[0.75]}\end{array}$ & $\begin{array}{c}-0.13 \\
(0.81) \\
{[1.33]}\end{array}$ & 0.28 & 38 \\
\hline$(1)^{\prime}$ & $\begin{array}{l}7.12 \\
(4.68)^{* * *} \\
{[5.29]^{* * *}}\end{array}$ & $\begin{array}{l}-1.37 \\
(1.68) \\
{[4.48]^{* * *}}\end{array}$ & & & $\begin{array}{c}-38.24 \\
(1.47) \\
{[1.76]^{*}}\end{array}$ & $\begin{array}{l}2.70 \\
(0.71) \\
{[0.80]}\end{array}$ & $\begin{array}{l}-1.08 \\
(0.11) \\
{[0.17]}\end{array}$ & $\begin{array}{c}3.96 \\
(0.57) \\
{[0.72]}\end{array}$ & $\begin{array}{l}-1.27 \\
(0.63) \\
{[0.52]}\end{array}$ & $\begin{array}{c}1.37 \\
(0.98) \\
{[1.10]}\end{array}$ & $\begin{array}{l}-0.15 \\
(0.92) \\
{[1.53]}\end{array}$ & 0.24 & 34 \\
\hline (2) & $\begin{array}{l}7.59 \\
(6.38) * * * \\
{[6.45]^{* * *}}\end{array}$ & & $\begin{array}{l}-2.24 \\
(3.06)^{* * *} \\
{[2.60]^{* *}}\end{array}$ & $\begin{array}{l}-0.36 \\
(0.50) \\
{[0.50]}\end{array}$ & $\begin{array}{r}-16.56 \\
(0.91) \\
{[0.90]}\end{array}$ & $\begin{array}{l}7.17 \\
(1.50) \\
{[1.37]}\end{array}$ & $\begin{array}{l}5.16 \\
(0.91) \\
{[0.66]}\end{array}$ & $\begin{array}{l}5.37 \\
(0.96) \\
{[0.97]}\end{array}$ & $\begin{array}{c}0.18 \\
(0.10) \\
{[0.10]}\end{array}$ & $\begin{array}{l}-0.03 \\
(0.03) \\
{[0.03]}\end{array}$ & $\begin{array}{c}0.08 \\
(0.56) \\
{[0.70]}\end{array}$ & 0.59 & 37 \\
\hline$(2)^{\prime}$ & $\begin{array}{l}7.01 \\
(6.25)^{* * *} \\
{[7.73]^{* * *}}\end{array}$ & & $\begin{array}{l}-2.11 \\
(3.35) * * * \\
{[4.33]^{* * *}}\end{array}$ & $\begin{array}{ll} & -0.09 \\
* & (0.14) \\
* & {[0.21]}\end{array}$ & $\begin{array}{l}-1.33 \\
(0.06) \\
{[0.07]}\end{array}$ & $\begin{array}{l}-1.39 \\
(0.47) \\
{[0.52]}\end{array}$ & $\begin{array}{l}-5.39 \\
(0.79) \\
{[0.99]}\end{array}$ & $\begin{array}{l}10.44 \\
(1.95)^{*} \\
{[2.19]^{* *}}\end{array}$ & $\begin{array}{l}-1.13 \\
(0.76) \\
{[0.55]}\end{array}$ & $\begin{array}{c}0.55 \\
(0.52) \\
{[0.55]}\end{array}$ & $\begin{array}{c}0.00 \\
(0.01) \\
{[0.01]}\end{array}$ & 0.59 & 34 \\
\hline
\end{tabular}

* $\quad$ significant at 10 percent level.

** significant at 5 percent level.

*** significant at 1 percent level.

Note: Absolute values of t-statistics are in parentheses. Absolute values of White t-statistics are in brackets.

In regression (1)' and (2)', the variable Inflation is replaced by the variable Monetary Policy.

Estimation results of year dummies are omitted in the table. 


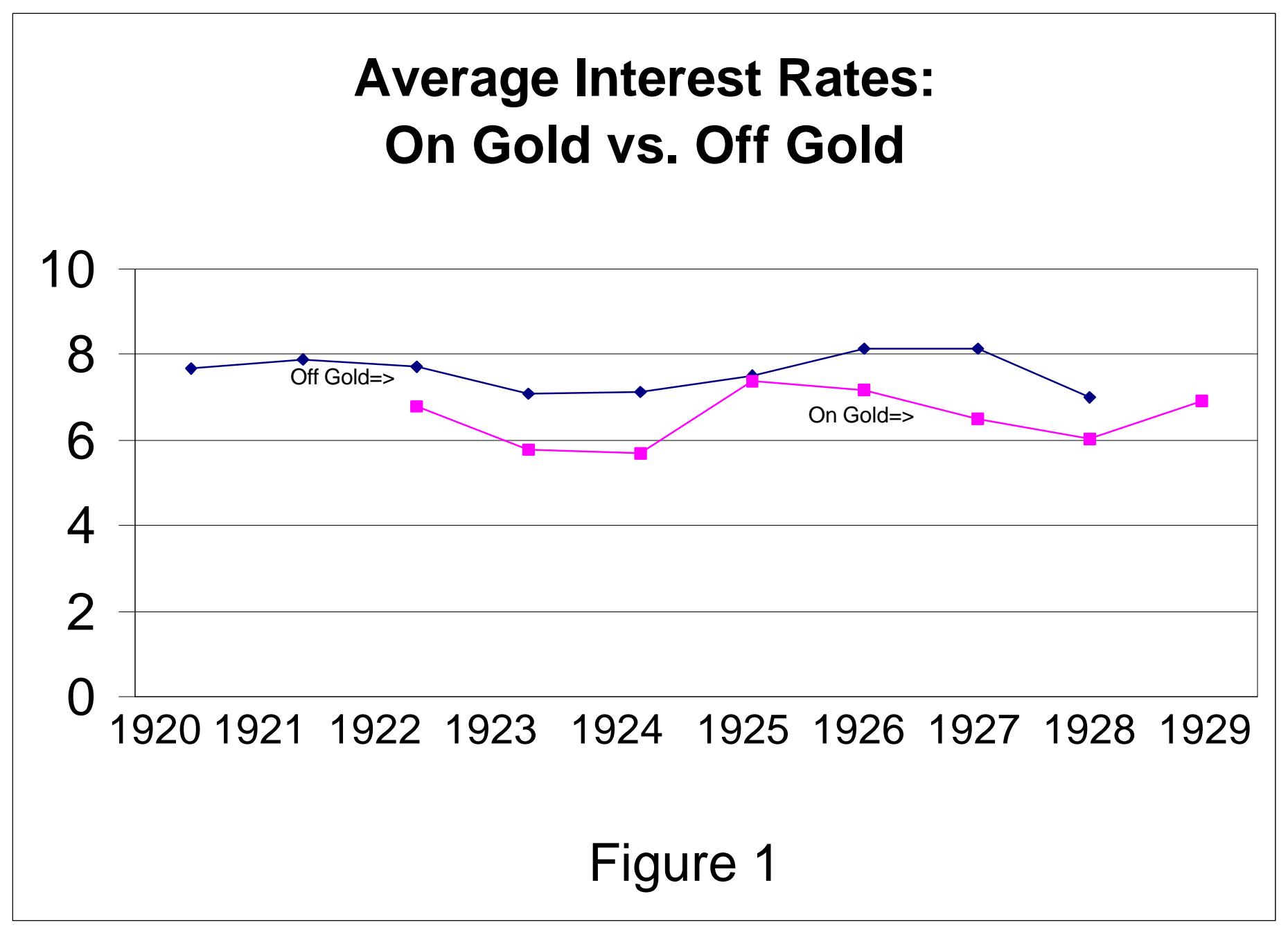




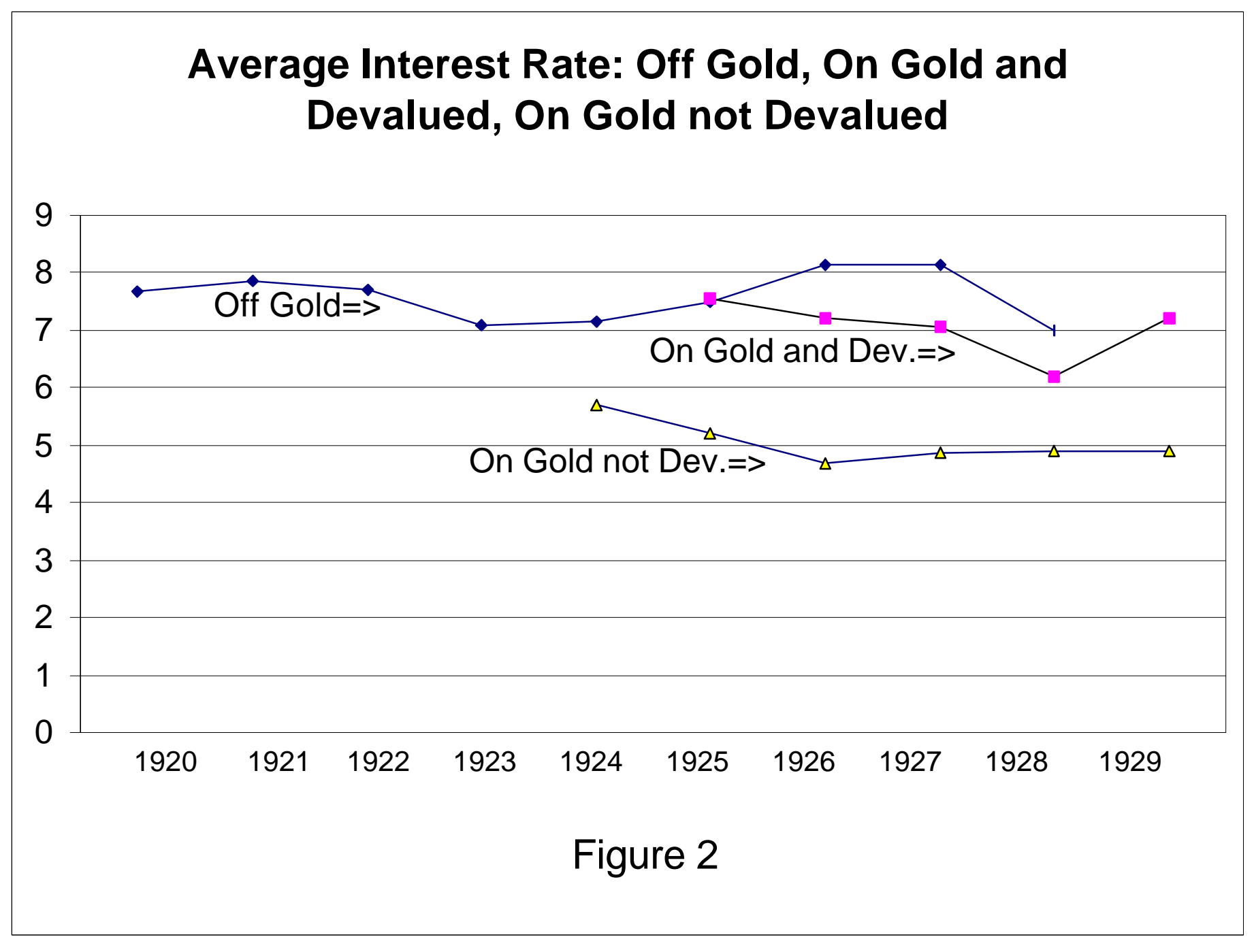




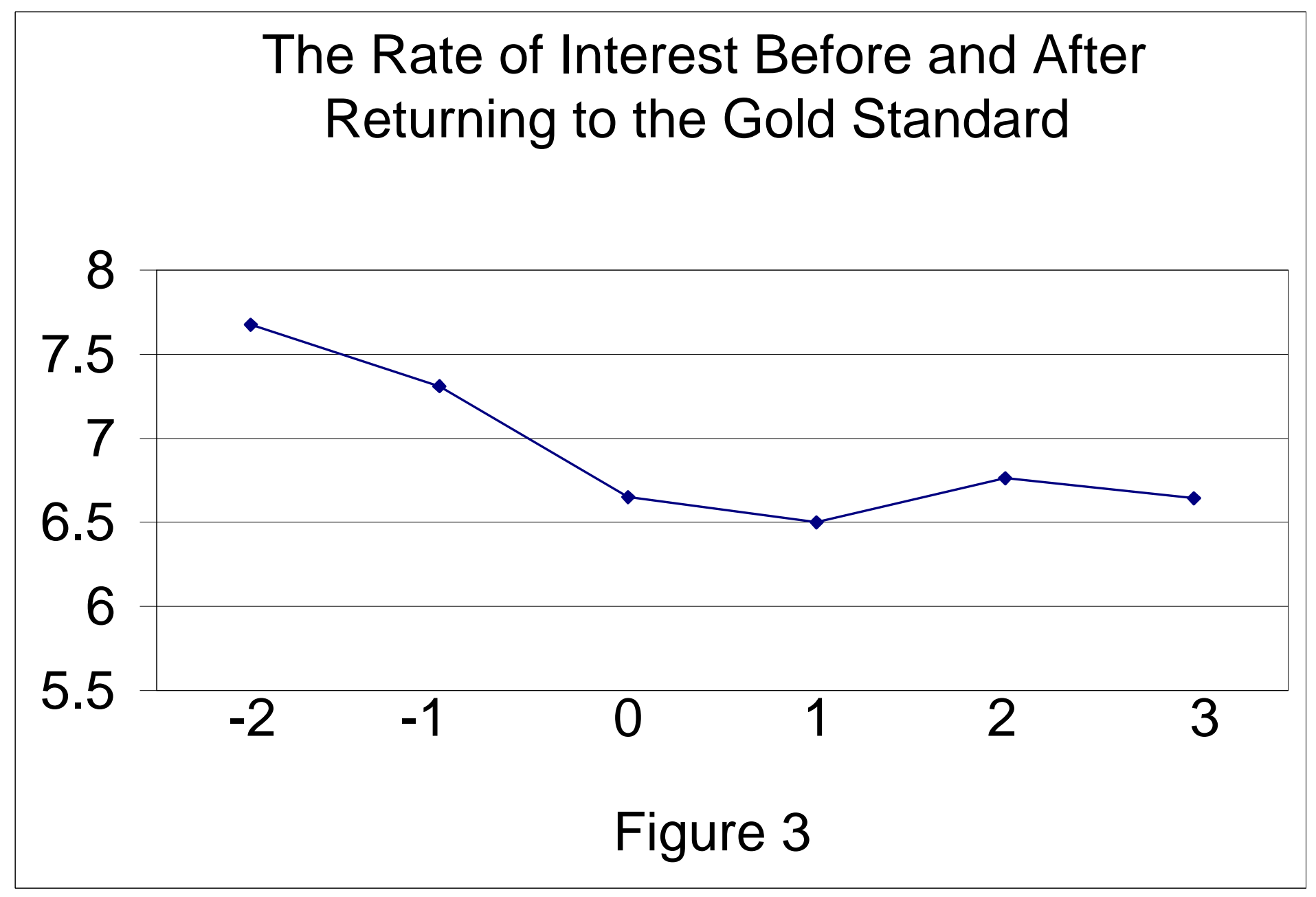

